Int. J. Dev. Biol. 59: 73-78 (2015)

doi: $10.1387 / \mathrm{ijdb} .150050 \mathrm{ac}$

\title{
Programmed cell death in the skin
}

\author{
ANTONIO COSTANZO ${ }^{1, *}$, FRANCESCA FAUSTI2, GIULIA SPALLONE², FRANCESCA MORETTI², \\ ALESSANDRA NARCISI ${ }^{1}$ and ELISABETTA BOTTI ${ }^{1}$
}

\author{
${ }^{1}$ Dermatology Unit, NESMOS Department, Sapienza University of Rome, and ${ }^{2}$ Department of Dermatology, Tor \\ Vergata University of Rome, Italy
}

\begin{abstract}
Differently from the other cells of the body, epidermal cells of the skin undergo a specific programmed cell death form named cornification. Many events take part to control this process, which has been described as a terminal differentiation program. Going from the innermost layer to the outermost, epidermal cells stop dividing, change their shape, acquire new cellular structures and strengthen their cytoskeleton. This is corroborated by the fact that during this physical transition they change their gene expression, reprogramming in some way their biochemical activity. The activation of critical enzymes, including proteases and transglutaminases is a fundamental cellular event. These enzymes are involved in building the supramolecular and cornified structures which confer resistance to the epidermis which carries out a vital function as a skin barrier, preserving the organism from various insults. Here we review current concepts about cornification and the mechanisms by which this process is preserved in species.
\end{abstract}

KEY WORDS: Cornification, apoptosis, skin disease

\section{Introduction}

The skin is the biggest organ in the body providing a solid barrier against environment insults, such as physical, chemical and biological insults. One of the most studied is damage derived from UVB radiation on skin, that leads the induction of apoptosis in targeted cells. Skin is composed by three major layers. The outermost is represented by squamous epithelium, the epidermis, which is continuously renewed, providing a waterproof barrier and creating the skin tone; keratinocytes are the major cell type in the epidermis and divide constantly to generate new cells. The programmed cell death or terminal differentiation program occurring to keratinocytes is referred to as cornification and it is distinguished from canonical apoptosis both morphologically than biochemically. Furthermore, while apoptosis is often associated with the removal of damaged cells in the organism, cornification functions as enhancer in the construction of the skin barrier, thus potentiating organism defense. Different degrees of the cornification process give rise to different cornified structures in skin, such as the nails, the hair shaft, the inner root sheath of hair follicle, the papillae of the tongue and so on. Another epidermis cell type is represented by melanocytes. These are neuroectoderm-derived cells that produce melanin, responsible for skin pigmentation. Underneath the epidermis is located the middle layer, the dermis, composed by connective tissue, with strong collagen and elastic fibres pierced by blood vessels. It also contains touch, pressure and pain sensors and is packed with hair follicles and sweat glands. The deeper subcutaneous tissue, the hypodermis, is composed by fat and connective tissue. The skin barrier is mainly composed of epidermis, which also functions as "guardian" for microbial infections. In fact, differentiating keratinocytes are able to produce many different antimicrobial peptides that preserve from bacteria, parasites and other affections in a constitutive or inducible manner (Schroder, 2010). During skin homeostasis a delicate and physiological turnover of proliferating and differentiating keratinocytes occurs. This guarantees for maintenance of skin barrier, while its deregulation is cause for many skin disorders and cancer.

\section{The epidermis}

The epidermis consists of sub-layers or strata characterized by different stages of keratinocytes differentiation (Fig.1). These strata are also distinguished by morphology and expression markers. Attached to the basement membrane resides the inner basal layer (stratum basale) responsible for proliferation and generation from a pool of pluripotent stem cells of new epidermal cells, that will differentiate towards the skin surface. The epidermal stem

Abbreviations used in this paper: PCD, programmed cell death.

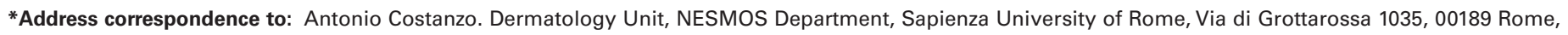
Italy. Telephone: +3906 33775744. E-mail: antonio.costanzo@uniroma1.it
}

Accepted: 6 May 2015.

ISSN: Online 1696-3547, Print 0214-6282 
cells reside in the basal layer and in the bulge of the hair follicle, a portion of the outer root sheath (Cotsarelis, 2006; Fuchs and Segre, 2000). These pluripotent stem cells give rise to transiently amplifying cells, which remain located in the basal layer and that represent proliferating keratinocytes. By asymmetric divisions, these cells generate new cells, which undergo the process of terminal differentiation along the successive layers. Notably, this terminal differentiation is coupled with changing in gene expression of these cells, which is mostly driven by $\mathrm{p} 63$ and other transcription factors (Koster et al., 2007).

\section{Differentiation of keratinocytes: the cornification process}

Just above the basal layer are stratified differentiating layers, in which instead of keratins $\mathrm{K} 5$ and $\mathrm{K} 14$, that characterize proliferating keratinocytes, differentiating keratinocytes express $\mathrm{K} 1, \mathrm{~K} 10$ and the Caspase-14. This occur in the spinous layer (stratum spinosum), in which keratinocytes exit from cell cycle starting terminal differentiation. At this stage cells strengthen their cytoskeleton through keratin filaments and increase contact to each others via desmosomes junctions. In the following granular layer (stratum granulosus), the cells become more flat and increase the expression of late differentiation markers. The expression of a gene cluster known as "epidermal differentiation complex" (EDC) generates proteins such as profilaggrin, a Caspase-14 substrate responsible for typical keratohyalin granules, which confer the name to the layer. Loss or reduction of profilaggrin expression results in impaired cornification and reduced skin barrier (Smith et al., 2006). EDC is also responsible for involucrin anad loricrin expression (Henry et al., 2012). Moreover, many lipids are synthesized and included in the lamellar bodies: these are then extruded from the apical side of the granular layer to form a waterproof envelope in the following last layer, the cornified layer (stratum corneum). The lamellar bodies also contains enzymes for the conversion of secreted lipids (Feingold, 2007). At the transition from the granular to cornified layer many events occurs. On this stage cells also lack of their nucleus that results degraded together with the other cellular organelles, while an intracellular increase of Ca2+activates transglutaminases (TGase) to crosslink cellular proteins to produce a cornified envelope (CE) close to the cell surface (Candi et al., 2005). Finally, keratins are the only kind of proteins present in the cornified cells, providing mechanical strength, thank to their structure and aggregation (Pan et al., 2013). Dead corneocytes are so completely surrounded by lipids that preserve against water loss and tightly connected by corneodesmosomes, which are cross-linked to the CE (Simpson et al., 2011). Proteolysis of corneodesmosomes leads to release of corneocytes from the outer cornified layer, a process called desquamation.

Many skin appendages undergo similar mechanism for differentiation of keratinocytes and cornification. For example hair and nails in which a special matrix of keratin-associated proteins (KRTAPs) keeps closer keratins characterized by more cross-linking compare to epidermis. This is due to keratinocyte expression in these structures of cysteine-rich keratins able to form multiple disulfide bridge, conferring additional mechanical resistance (Thibaut et al., 2009). Activation of transglutaminases for cornification process was reported, but the lipidic matrix which characterized the cornified layer is lost, probably due to the absence of lamellar bodies extrusion. This, together with the absence of proteolysis and the maintenance of desmosomes, leads to unidirectional growth of this epidermal structure (Morioka, 2009; Paus and Cotsarelis, 1999; Thibaut et al., 2009).

\section{Programmed cell death and cornification}

Differently from apoptosis, keratinocytes terminal differentiation implicates a simultaneous process which involves a whole layer of cells, whose function is to constitute a solid barrier against environment insults. The correct cell turnover in the outer surface is guaranteed by desquamation process. Despite the difference with classical apoptosis, the protease activity of caspases is still required. Among the apoptotic caspases, caspase 3 is the only one described activated in embryonic skin homeostasis: both expression and dowregulation in epidermis development was reported (Okuyama et al., 2004). A role for cytochrome $C$ release during in vitro terminal differentiation of keratinocytes was also described. Noteworthy, it is not functional for apoptosis activation via apoptosome formation but for transcription factors activation and gene expression (Allombert-Blaise et al., 2003; Grether-Beck et al., 2003). In fact, the expression of some anti-apototic Bcl-2 family members, such as Bcl-2 itself, appears to be downregulated during differentiation of keratinocytes in the suprabasal layers, while pro-apoptotic Bax and Bak increase their expression. Despite this, no impairments in

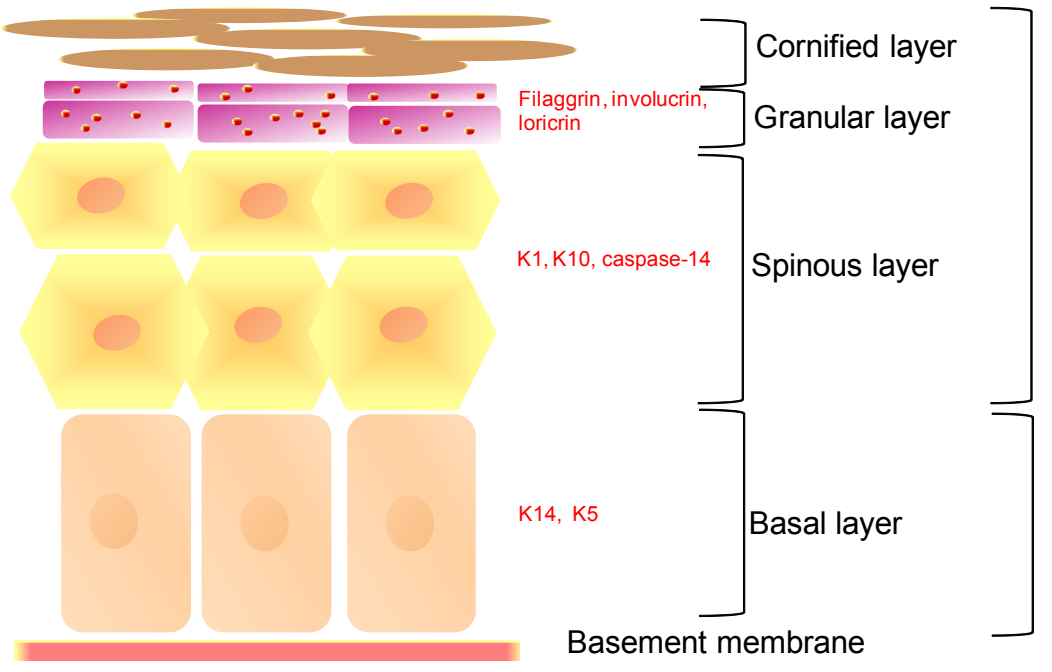

Fig.1 Structure and expression markers of the epidermis. During the cornification process, keratinocytes move from the basal layer towards the cutaneous surface, undergoing specific morphological modifications and expressing markers which allow to distinguish four histological layers. The basal layer is a monolayer of proliferating stem cells with expression of keratins 5 and 14 . In the spinous layer the keratinocytes start to produce keratins 1 and 10; they become poligonal and tightly connected through desmosomes. In the granular layer, keratinocytes become more flat, loose their nuclei and appear granular with increased expression of late differentiation markers such as filaggrin, involucrin and loricrin. In the cornified layer, dead keratinocytes, called corneocytes, are composed of keratin filaments that are aggregated in supramolecular structures. 
epidermis development was observed in these Bcl2-family members knock-out mice (Krajewski et al., 1996; Krajewski et al., 1994; Lu et al., 1993), with the exception of Bcl-2 in the hair follicle. Also $\beta$-integrins, which mediate the adhesion of keratinocytes with the extracellular matrix and so regulate the detachment of cells and the initiation of terminal differentiation, are able to induce an apoptotic signal cascade in suspension keratinocytes, when unoccupied (Levy et al., 2000). A putative mechanism for preserving vitality of soprabasal keratinocytes in vivo. Finally, suppression of stem cells transcription factor c-Kit induces apoptosis in melanoblasts of mouse embryos (Ito et al., 1999).

Interestingly, the hair follicle undergoes cyclic activity through periods of active hair growth (Anagen), involution due to apoptosis process (Catagen), hair shedding (Exogen) and a resting phase (Telogen). The Bcl-2 knock-out mice show a prolonged growth phase, while transgenic mice show acceleration of this phase (Muller-Rover et al., 2000; Veis et al., 1993). Also hair graying occurs through apoptosis of melanocytes in the involution phase, driven by pro-apoptotic Bim (Bouillet et al., 2001). Keratin-17 knockout mice display strong apoptosis in the hair matrix, coupled with activation of pro-apoptotic Bmf and Bim. These, thanks to their localization at the cytoskeleton level, sense damage in structural integrity and induce the apoptotic program (Puthalakath et al., 1999; Puthalakath et al., 2001).

\section{Metabolic activity in cornification process}

As mentioned above, the non apoptotic Caspase 14 is essential for normal skin development. It is expressed and activated in differentiating soprabasal layers. Knock-out mice for this protease show impairments in the formation of cornified layer with consequent sensitivity to UVB radiation and inability to maintain skin hydration (Denecker et al., 2007; Lippens S, 2000; Lippens S, 2003). Profilaggrin is a direct caspase 14 substrate, and its degradation concurs in the formation of keratohyalin granules and in the organization of keratin filaments to robust keratinocytes cytoskeleton. Furthermore, in the upper cornified layers deficient mice show a reduction in filaggrin degradation and the absence of derived natural moisturizing factors and urocanic acid, which prevents UVB radiation-induced damage (Hoste E, 2011). Another important biochemical aspect of cornification, which leads keratinocytes to become death corneocytes, is the activation of transglutaminases. This is probably due to signaling of damaged lysosomes, with consequent cathepsins release and damaged mitochondria, that induce an increase of intracellular $\mathrm{Ca}^{+2}$ levels (Candi et al., 2005). Transglutaminase induction is functional in the building of the supramolecular structures constituted by crosslinked keratin filaments and the CE. Suppression of transglutaminase activity, TGase1 in particular, is associated with disturbances in the cornification process with no formation of $\mathrm{CE}$ and nuclei retention at the cornified layer level (Kuramoto et al., 2002; Matsuki et al., 1998).

The degradation of nucleic acids during cornification process is a metabolic event very conserved in species (Maddin et al., 2009). Especially the DNase1L2 appears to be activated and responsible for the DNA digestion process during terminal differentiation of keratinocytes (Fischer et al., 2007). Evidences for a putative role of DNase2 were also reported (Fischer $\mathrm{H}, 2011$ ). Its expression is almost tissue-specific for skin, witnessing almost a fundamental role in this process. DNase1L2 is essential for the removal of nuclear DNA during cornification of keratinocytes in vitro, while some evidences show that it is probably able to digest also mitochondrial DNA (Bouillet et al., 2001). Despite this, the suppression of DNase1L2 activity in Knock-out mice does not show significant relevance in DNA degradation process during the formation of the murine interfollicular cornified layer. However, in the mouse model the DNase ablation leads to impairments in the terminal differentiation of keratinocytes of hard cornified structure, such as hair, nail and tongue papillae (Bouillet et al., 2001). These differences are probably due to specific variants of cornification process between human and mouse. Interestingly, the cornified layer is also depleted of great amount of RNA, thank to the increased expression and activity of some specific RNases (Abtin et al., 2009).

\section{Anti-apoptotic activity in developmental epidermis}

Many lines of evidence indicate that NF- $\kappa B$ is a fundamental factor in preventing keratinocytes apoptosis during terminal differentiation, both in normal and in pathological conditions of the skin. In its active DNA-binding form, NF- $\mathrm{KB}$ is a heterogeneous collection of dimers, composed by different combinations of mem-

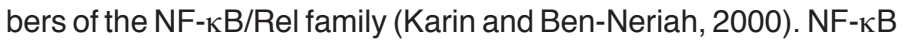
transcription factors play an important role in integrating multiple stress stimuli and regulating cellular responses in inflammation, infection and so on (Bonizzi G, 2004). NF-кB dimers can made up of five homologous subunits: p50/NF-кB1, p52/NFк-B2, RelA/ p65, c-Rel and RelB, which reside in the cytoplasmic compartment of unstimulated cells by specific proteins, the $1 \kappa B s$, inhibitors of NF- $\kappa B$ transcription factor. A partial redundancy in the NF- $\kappa B$ subunits functions was reported (Rebholz B, 2007). The IkB kinases, representing by IKK $\alpha, I K K \beta$ and NEMO (IKK $\gamma)$, phosphorylates the inhibitors I $\mathrm{KB}$ proteins, targeting them for ubiquitination and consequent degradation. Thus, the NF- $\kappa \mathrm{B}$ factor is released and migrates into the nucleus when activates its pro-survival and antiapoptotic target genes. The kinase IKK $\alpha$ shows a further activity in differentiating keratinocytes of stratified epithelia. As a dimer, it moves in to the nucleus and represses proliferative genes, as part of TGF $\beta$ pathway, a major tumor suppressor pathway during early carcinogenesis (Marinari B, 2008).

$\mathrm{NF}-\kappa \mathrm{B}$ is not activated in the proliferating keratinocytes, but its induction and nuclear translocation is triggered by differentiation (Seitz et al., 1998). Anti-apoptotic NF-кB target genes, such as cIAP-1, c-IAP-2, TRAF1 and TRAF2 appears to be up-regulated in differentiating keratinocytes (Qin et al., 1999). Combined deletions of different NF- $\mathrm{KB}$ subunits in mice lead to common reductions in the proliferative potential of the basal cells (Gugasyan et al., 2004; Zhang et al., 2004). Nonetheless, the main role for NF-кB transcription factor is to provide protection against apoptosis during inflammation. Awide range of stimuli, including tumor necrosis factor alpha (TNF $\alpha$ ), lipopolysaccharide (LPS) and interleukin-1 stimulation induce the activation of the IKK complex to phosphorylates the NF-kB inhibitors, leading to induction of NF-кB nuclear activity (Hacker and Karin, 2006). Furthermore Knock-out mice for crucial members of NF-kB pathway show premature keratinocytes apoptosis and pronounced inflammatory response (Makris et al., 2000).

Another important pathway implicated in protection of keratinocytes from apoptosis is the PI3K/AKT pathway, activated from the epidermal growth factor receptor (EGFR) and the insulin growth factor-1 receptor (IGF1R). Deleted mice for AKT expression show a thinner skin and less hair follicles, compared to normal (Peng et 
al., 2003; Yang et al., 2005). It was shown that AKT phopshorylates the pro-apoptotic BAD, a Bcl-2 family member, thus inhibiting it (Datta et al., 1997). Furthermore, does exist an interplay between AKT and NF-KB pathway. It is believed that each of the two is able to activate the other (Meng F, 2002; Ozes et al., 1999). Many lines of evidence indicate that also the ERK1/2 pathway is involved in anti-apoptotic mechanisms in keratinocytes (Jin et al., 2005; Rygiel et al., 2008).

\section{PCD and skin pathology}

One of the major environment insult which occurs to skin is that derived by exposure to the ultraviolet radiation (UVR). The ultraviolet spectrum is composed by three kind of radiations: UVC, which are filtered by the atmosphere, being therefore not harmful to the skin and UVA and UVB, certainly more "insidious" (Fig.2). Both are responsible for sunburn, tanning, photoaging and induction of carcinogenesis in skin. At the cellular level, UVA and UVB radiations, particularly the UVA, are cause of increased levels and accumulation of reactive oxygen species (ROS) and contribute to apoptosis in keratinocytes (Ichihashi et al., 2003). Moreover, UVB radiation is able to induce mutations at nucleotides level due to the formation of photolesions and nucleotide conversion (Matsunaga et al., 1991). The main repair system acting in UVBdamaged cells is nucleotide excision repair (NER); but when this repair is not sufficient, cells accumulate mutations which are so propagated in daughter cells, laying the foundation for transformation and carcinogenesis. Noteworthy, keratinocytes are able to counteract photadamaging through the induction of various cellular pathways, including cell cycle arrest and DNA repair, inflammation and apoptosis. Macroscopically, apoptosis leads to the formation of sun-burn cell (SBC), which represent apoptotic keratinocytes with pyknotic nuclei and eosinophilic cytoplasm (Civatte bodies) (Daniels et al., 1961).
Apoptosis, as well as SBC formation are mainly attributable to the activation of the tumor suppression p53 protein (Bruins W, 2004), which is well known as "guardian of genome" (Lane, 1992). P53 plays a critical role in the activation of UVB radiation apoptotic response in keratinocytes, through transcription-dependent and independent mechanism and inducing both extrinsic than intrinsic apoptotic pathways (Caelles et al., 1994; Wagner et al., 1994). UVB-induced damage leads to inactivation of MDM2, a major mediator for p53 ubiquitination and degradation. Consequently, p53 results stabilized. This stabilization goes through ATM and FRAP kinases activation that is responsible for signaling damage on p53 by phosphorylating it at ser389 residue (Shiloh, 2003). P53 performs its apoptotic function mainly through the modulation of many Bcl-2 family members, including Bcl-2, Bcl-xL Bax, PUMA and Noxa (Erster and Moll, 2005; Naik et al., 2007; Thornborrow et al., 2002; Zilfou et al., 2005). Among them, Noxa seems to be a key target for p53 in apoptosis of damaged keratinocytes: Noxa Knock-out mice display suppression of apoptosis in UVB exposed keratinocytes.

It was reported that another p53 family member is especially involved in modulating UVB-induced apoptosis: p63, which shares many target genes with p53. Knock-out mice for this gene display the most dramatic skin phenotype with no epidermis, squamous epithelia and epithelial appendages (Yang A, 1999). Six different p63 isoforms do exist, containing or lacking a canonical transactivation domain (TA and $\Delta \mathrm{N}$ isoforms). The most expressed isoform in proliferating keratinocytes is $\Delta \mathrm{Np} 63 \alpha$, mainly at the basal layer level. In proliferating keratinocytes $\Delta \mathrm{Np} 63 \alpha$ occupies p53 responsive elements on pro-apoptotic target genes, thus inhibiting p53 binding to- and transactivation of these genes (Fig.2). Our previous results indicated that when keratinocytes are exposed to UVB radiation p38MAPK phosphorylates $\triangle \mathrm{Np} 63 \alpha$, thus inducing its detachment from apoptotic p53 target genes and allowing the rapid activation of p53-dependent transcriptional apoptotic program (Papoutsaki et
Fig. 2. Aftermath of ultraviolet A-B-C radiation on skin. UV-C are shielded by the atmosphere and do not reach the skin. UV-B get through the epidermis causing ROS formation (release), activation of p38 with consequent $\triangle N$ p63 detachment and leading to activation of p53 apoptotic genes. On the contrary, $\triangle N p 63$ leads a suppressive activity on p53 apoptotic function in unstimulated keratinocytes. UV-A is responsible for skin aging.

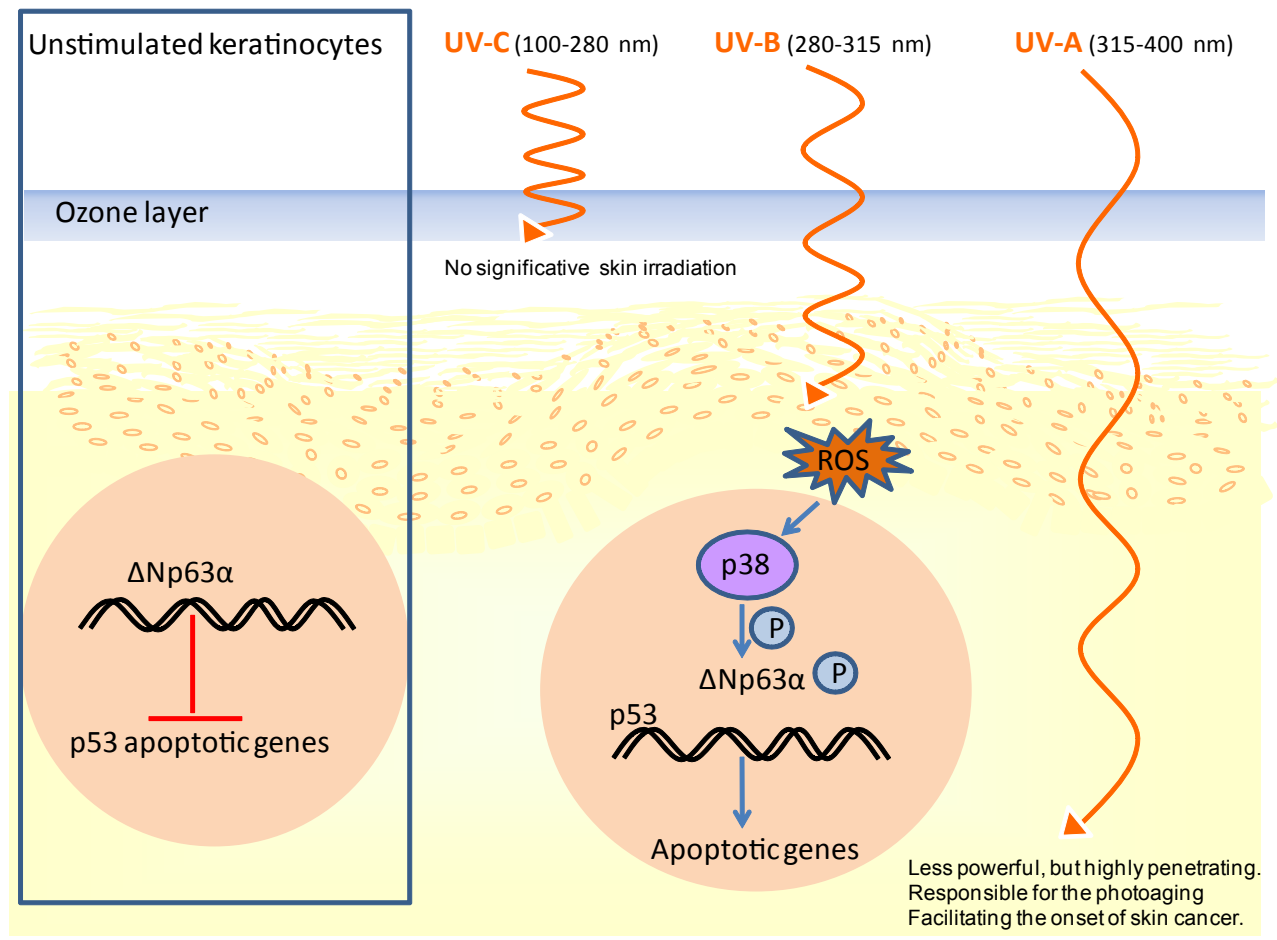


al., 2005). Interestingly, the $\Delta \mathrm{Np} 63 \alpha$ knock-out mouse is a model for ectodermal dysplasia and clefting (AEC) (Koster et al., 2009), a skin disorder characterized by fragility and missing patches of skin (erosions). These lesions are characterized by suprabasal epidermal proliferation, delayed terminal differentiation, and basement membrane abnormalities. This implies that $\Delta N p 63 \alpha$ play a critical role in the correct development of skin through modulating apoptosis in a spatio-temporal manner.

\section{Conclusion}

The epidermis represents an interesting model to study the relevance of programmed cell death in normal development and pathology. In fact, different apoptotic pathways coexist in the epidermis to regulate its homeostasis and response to stressors. Programmed cell death of keratinocytes in the granular layer occurs continuously and assures the correct development of the stratum corneum, while programmed cell death of lower layers' keratinocytes occurs in response to DNA damage and prevents cell transformation. These processes are tightly regulated by a different set of transcription factors and key enzymes that are activated at different stages of the differentiation process. The deep knowledge of these processes and the ability to modulate them pharmacologically can be easily translated to other systems thus explaining disease development in other organs and helping in identifying relevant therapeutical targets.

\section{Acknowledgments}

This work was supported by grants from AIRC, FIRB-IDEAS, Telethon and National Psoriasis foundation to A.C.

\section{References}

ABTIN, A., ECKHART, L., MILDNER, M., GHANNADAN, M., HARDER, J., SCHRODER, J.M., TSCHACHLER, E., (2009). Degradation by stratum corneum proteases prevents endogenous RNase inhibitor from blocking antimicrobial activities of RNase 5 and RNase 7. J. Invest. Dermatol. 129: 2193-2201.

ALLOMBERT-BLAISE, C., TAMIJI, S., MORTIER, L., FAUVEL, H., TUAL, M., DELAPORTE, E., PIETTE, F., DELASSALE, E.M., FORMSTECHER, P., MARCHETTI, P., POLAKOWSKA, R., (2003). Terminal differentiation of human epidermal keratinocytes involves mitochondria- and caspase-dependent cell death pathway. Cell Death Differ 10: 850-852.

BONIZZI G, K.M., (2004). The two NF-kappaB activation pathways and their role in innate and adaptive immunity. Trends Immunol.: 280-288.

BOUILLET, P., CORY, S., ZHANG, L.C., STRASSER, A., ADAMS, J.M., (2001). Degenerative disorders caused by $\mathrm{Bcl}-2$ deficiency prevented by loss of its $\mathrm{BH} 3$-only antagonist Bim. Dev Cell 1: 645-653.

BRUINS W, Z.E., ATTARDI LD, IWAKUMA T, HOOGERVORST EM, BEEMS RB, MIRANDA B, VAN OOSTROM CT, VAN DEN BERG J, VAN DEN AARDWEG GJ, LOZANO G, VAN STEEG H, JACKS T, DE VRIES A., (2004). Increased sensitivity to UV radiation in mice with a p53 point mutation at Ser389. Mol Cell Biol: 8884-8894.

CAELLES, C., HELMBERG, A., KARIN, M., (1994). p53-dependent apoptosis in the absence of transcriptional activation of p53-target genes. Nature 370: 220-223.

CANDI, E., SCHMIDT, R., MELINO, G., (2005). The cornified envelope: a model of cell death in the skin. Nat Rev Mol Cell Biol. 6: 328-340.

COTSARELIS, G., (2006). Epithelial stem cells: a folliculocentric view. J. Invest. Dermatol. 126: 1459-1468.

DANIELS, F., JR., BROPHY, D., LOBITZ, W.C., JR., (1961). Histochemical responses of human skin following ultraviolet irradiation. J. Invest. Dermatol. 37: 351-357.

DATTA, S.R., DUDEK, H., TAO, X., MASTERS, S., FU, H., GOTOH, Y., GREENBERG, M.E., 1997. Akt phosphorylation of BAD couples survival signals to the cell-intrinsic death machinery. Cell 91: 231-241.

DENECKER, G., HOSTE, E., GILBERT, B., HOCHEPIED, T., OVAERE, P., LIPPENS, S., VAN DEN BROECKE, C., VAN DAMME, P., D'HERDE, K., HACHEM, J.P., BORGONIE, G., PRESLAND, R.B., SCHOONJANS, L., LIBERT, C., VANDEKERCKHOVE, J., GEVAERT, K., VANDENABEELE, P., DECLERCQ, W., (2007). Caspase-14 protects against epidermal UVB photodamage and water loss. Nature Cell Biol 9: 666-674.

ERSTER, S., MOLL, U.M., (2005). Stress-induced p53 runs a transcription-independent death program. Biochem Biophys Res Commun 331: 843-850.

FEINGOLD, K.R., (2007). The importance of lipids in cutaneous function. J Lipid Res 48: 2529-2530.

FISCHER, H., ECKHART, L., MILDNER, M., JAEGER, K., BUCHBERGER, M., GHANNADAN, M., TSCHACHLER, E., (2007). DNase1L2 degrades nuclear DNA during corneocyte formation. J. Invest. Dermatol.127: 24-30.

FISCHER, H., SCHERZ, J., SZABO, S., MILDNER, M., BENARAFA, C., TORRIGLIA, A., TSCHACHLER, E., ECKHART, L., (2011). DNase 2 is the main DNA-degrading enzyme of the stratum corneum. PLoS One 6: 1-9.

FUCHS, E., SEGRE, J.A., (2000). Stem cells: a new lease on life. Cell 100: 143-155.

GRETHER-BECK, S., FELSNER, I., BRENDEN, H., KRUTMANN, J., (2003). Mitochondrial cytochrome $\mathrm{c}$ release mediates ceramide-induced activator protein 2 activation and gene expression in keratinocytes. J Biol Chem 278: 47498-47507.

GUGASYAN, R., VOSS, A., VARIGOS, G., THOMAS, T., GRUMONT, R.J., KAUR, P., GRIGORIADIS, G., GERONDAKIS, S., (2004). The transcription factors c-rel and RelAcontrol epidermal development and homeostasis in embryonic and adult skin via distinct mechanisms. Mol Cell Biol 24: 5733-5745.

HACKER, H., KARIN, M., (2006). Regulation and function of IKK and IKK-related kinases. Sci STKE 2006, re13.

HENRY, J., TOULZA, E., HSU, C.Y., PELLERIN, L., BALICA, S., MAZEREEUWHAUTIER, J., PAUL, C., SERRE, G., JONCA, N., SIMON, M., (2012). Update on the epidermal differentiation complex. Front Biosci 17, 1517-1532.

HOSTE E, K.P., DEVOS M, DENECKER G, KEZIC S, YAU N, GILBERT B, LIPPENS S, DE GROOTE P, ROELANDT R, VAN DAMME P, GEVAERTK, PRESLAND RB, TAKAHARA H, PUPPELS G, CASPERS P, VANDENABEELE P, DECLERCQ W., (2011). Caspase-14 is required for filaggrin degradation to natural moisturizing factors in the skin. J. Invest. Dermatol.131, 2233-2241.

ICHIHASHI, M., UEDA, M., BUDIYANTO, A., BITO, T., OKA, M., FUKUNAGA, M., TSURU, K., HORIKAWA, T., (2003). UV-induced skin damage. Toxicology 189, 21-39.

ITO, M., KAWA, Y., ONO, H., OKURA, M., BABA, T., KUBOTA, Y., NISHIKAWA, S.I., MIZOGUCHI, M., (1999). Removal of stem cell factor or addition of monoclonal anti-c-KIT antibody induces apoptosis in murine melanocyte precursors. J. Invest. Dermatol.112, 796-801.

JIN, S., ZHUO, Y., GUO, W., FIELD, J., (2005). p21-activated Kinase 1 (Pak1)dependent phosphorylation of Raf-1 regulates its mitochondrial localization, phosphorylation of BAD, and Bcl-2 association. J Biol Chem 280: 24698-24705.

KARIN, M., BEN-NERIAH, Y., (2000). Phosphorylation meets ubiquitination: the control of NF-[kappa]B activity. Annu Rev Immunol 18: 621-663.

KOSTER, M.I., DAI, D., MARINARI, B., SANO, Y., COSTANZO, A., KARIN, M., ROOP, D.R., (2007). p63 induces key target genes required for epidermal morphogenesis. Proc Natl Acad Sci USA 104: 3255-3260.

KOSTER, M.I., MARINARI, B., PAYNE, A.S., KANTAPUTRA, P.N., COSTANZO A., ROOP, D.R., (2009). DeltaNp63 knockdown mice: A mouse model for AEC syndrome. Am J Med Genet. Part A 149A: 1942-1947.

KRAJEWSKI, S., KRAJEWSKA, M., REED, J.C., (1996). Immunohistochemical analysis of in vivo patterns of Bak expression, a proapoptotic member of the Bcl-2 protein family. Cancer Res 56: 2849-2855.

KRAJEWSKI, S., KRAJEWSKA, M., SHABAIK, A., WANG, H.G., IRIE, S., FONG, L., REED, J.C., (1994). Immunohistochemical analysis of in vivo patterns of $\mathrm{Bcl}-\mathrm{X}$ expression. Cancer Res 54: 5501-5507.

KURAMOTO, N., TAKIZAWA, T., TAKIZAWA, T., MATSUKI, M., MORIOKA, H., ROBINSON, J.M., YAMANISHI, K., (2002). Development of ichthyosiform skin compensates for defective permeability barrier function in mice lacking transglutaminase 1. J Clin Invest 109: 243-250.

LANE, D.P., (1992). Cancer. p53, guardian of the genome. Nature 358: 15-16.

LEVY, L., BROAD, S., DIEKMANN, D., EVANS, R.D., WATT, F.M., (2000). beta1 inte- 
grins regulate keratinocyte adhesion and differentiation by distinct mechanisms. Mol Biol Cell 11: 453-466.

LIPPENS S, K.M., KNAAPEN M, MORTIER L, POLAKOWSKA R, VERHEYEN A, GARMYN M, ZWIJSEN A, FORMSTECHER P, HUYLEBROECK D, VANDENABEELE P, DECLERCQ W., (2000). Epidermal differentiation does not involve the pro-apoptotic executioner caspases, but is associated with caspase-14 induction and processing. Cell Death Differ 7: 1218-1224.

LIPPENSS, V.C., VANDAMME E, TSCHACHLERE, VANDENABEELEP, DECLERCQ W, (2003). Caspase-14 is expressed in the epidermis, the choroid plexus, the retinal pigment epithelium and thymic Hassall's bodies. Cell Death Differ, 257-259.

LU, Q.L., POULSOM, R., WONG, L., HANBY, A.M., (1993). Bcl-2 expression in adult and embryonic non-haematopoietic tissues. J Pathol 169: 431-437.

MADDIN, H.C., ECKHART, L., JAEGER, K., RUSSELL, A.P., GHANNADAN, M., (2009). The anatomy and development of the claws of Xenopus laevis (Lissamphibia: Anura) reveal alternate pathways of structural evolution in the integument of tetrapods. J Anat 214: 607-619.

MAKRIS, C., GODFREY, V.L., KRAHN-SENFTLEBEN, G., TAKAHASHI, T., ROBERTS, J.L., SCHWARZ, T., FENG, L., JOHNSON, R.S., KARIN, M., (2000). Female mice heterozygous for IKK gamma/NEMO deficiencies develop a dermatopathy similar to the human X-linked disorder incontinentia pigmenti. Mol Cell5: 969-979.

MARINARI B, MORETTI F., BOTTI E, GIUSTIZIERI ML, DESCARGUES P, GIUNTA A, STOLFI C, BALLARO C, PAPOUTSAKI M, ALEMÀ S, MONTELEONE G, CHIMENTI S, KARIN M, COSTANZO A., (2008). The tumor suppressor activity of IKKalpha in stratified epithelia is exerted in part via the TGF-beta antiproliferative pathway. Proc Natl Acad Sci USA.105: 17091-17096.

MATSUKI, M., YAMASHITA, F., ISHIDA-YAMAMOTO, A., YAMADA, K., KINOSHITA, C., FUSHIKI, S., UEDA, E., MORISHIMA, Y., TABATA, K., YASUNO, H., HASHIDA, M., IIZUKA, H., IKAWA, M., OKABE, M., KONDOH, G., KINOSHITA, T., TAKEDA, J., YAMANISHI, K., (1998). Defective stratum corneum and early neonatal death in mice lacking the gene for transglutaminase 1 (keratinocyte transglutaminase). Proc Natl Acad Sci USA. 95: 1044-1049.

MATSUNAGA, T., HIEDA, K., NIKAIDO, O., (1991). Wavelength dependent formation of thymine dimers and (6-4) photoproducts in DNA by monochromatic ultraviolet light ranging from 150 to $365 \mathrm{~nm}$. Photochem Photobiol 54: 403-410.

MENG F, L.L., CHIN PC, D'MELLO SR, (2002). Akt is a downstream target of NFkappa B. J Biol Chem 277: 29674-29680.

MORIOKA, K., (2009). A guide to hair follicle analysis by transmission electron microscopy: technique and practice. Exp Dermatol 18: 577-582.

MULLER-ROVER, S., ROSSITER, H., PAUS, R., HANDJISKI, B., PETERS, E.M., MURPHY, J.E., MECKLENBURG, L., KUPPER, T.S., (2000). Overexpression of $\mathrm{Bcl}-2$ protects from ultraviolet $\mathrm{B}$-induced apoptosis but promotes hair follicle regression and chemotherapy-induced alopecia. Am J Pathol 156: 1395-1405.

NAIK, E., MICHALAK, E.M., VILLUNGER, A., ADAMS, J.M., STRASSER, A., (2007). Ultraviolet radiation triggers apoptosis of fibroblasts and skin keratinocytes mainly via the BH3-only protein Noxa. J Cell Biol 176: 415-424.

OKUYAMA, R., NGUYEN, B.C., TALORA, C., OGAWA, E., TOMMASI DI VIGNANO, A., LIOUMI, M., CHIORINO, G., TAGAMI, H., WOO, M., DOTTO, G.P., (2004). High commitment of embryonic keratinocytes to terminal differentiation through a Notch1-caspase 3 regulatory mechanism. Dev Cell 6: 551-562.

OZES, O.N., MAYO, L.D., GUSTIN, J.A., PFEFFER, S.R., PFEFFER, L.M., DONNER, D.B., (1999). NF-kappaB activation by tumour necrosis factor requires the Akt serine-threonine kinase. Nature 401: 82-85.

PAN, X., HOBBS, R.P., COULOMBE, P.A., (2013). The expanding significance of keratin intermediate filaments in normal and diseased epithelia. Curr Opin Cell Biol 25: 47-56.

PAPOUTSAKI, M., MORETTI, F., LANZA, M., MARINARI, B., SARTORELLI, V., GUERRINI, L., CHIMENTI, S., LEVRERO, M., COSTANZO, A., (2005). A p38dependent pathway regulates DeltaNp63 DNA binding to p53-dependent promoters in UV-induced apoptosis of keratinocytes. Oncogene 24: 6970-6975.

PAUS, R., COTSARELIS, G., (1999). The biology of hair follicles. N Engl J Med 341: $491-497$

PENG, X.D., XU, P.Z., CHEN, M.L., HAHN-WINDGASSEN, A., SKEEN, J., JACOBS J., SUNDARARAJAN, D., CHEN, W.S., CRAWFORD, S.E., COLEMAN, K.G., HAY, N., (2003). Dwarfism, impaired skin development, skeletal muscle atrophy, delayed bone development, and impeded adipogenesis in mice lacking Akt1 and Akt2. Genes Dev 17: 1352-1365.

PUTHALAKATH, H., HUANG, D.C., O'REILLY, L.A., KING, S.M., STRASSER, A. (1999). The proapoptotic activity of the Bcl-2 family member Bim is regulated by interaction with the dynein motor complex. Mol Cell 3: 287-296.

PUTHALAKATH, H., VILLUNGER, A., O'REILLY, L.A., BEAUMONT, J.G., COULTAS L., CHENEY, R.E., HUANG, D.C., STRASSER, A., (2001). Bmf: a proapoptotic $\mathrm{BH} 3-$ only protein regulated by interaction with the myosin $\mathrm{V}$ actin motor complex, activated by anoikis. Science 293: 1829-1832.

QIN, J.Z., CHATURVEDI, V., DENNING, M.F., CHOUBEY, D., DIAZ, M.O., NICKOLOFF, B.J., (1999). Role of NF-kappaB in the apoptotic-resistant phenotype of keratinocytes. J Biol Chem 274: 37957-37964.

REBHOLZ B, H.I., ECKELT B, PAXIAN S, FLAIG MJ, GHORESCHI K, NEDOSPASOV SA, MAILHAMMER R, DEBEY-PASCHER S, SCHULTZE JL, WEINDL G, FÖRSTER I, HUSS R, STRATIS A, RUZICKA T, RÖCKEN M, PFEFFER K, SCHMID RM, RUPEC RA, (2007). Crosstalk between keratinocytes and adaptive immune cells in an IkappaBalpha protein-mediated inflammatory disease of the skin. Immunity: 296-307.

RYGIEL, T.P., MERTENS, A.E., STRUMANE, K., VAN DER KAMMEN, R., COLLARD, J.G., (2008). The Rac activator Tiam1 prevents keratinocyte apoptosis by controlling ROS-mediated ERK phosphorylation. J Cell Sci 121: 1183-1192.

SCHRODER, J.M., (2010). The role of keratinocytes in defense against infection. Curr Opin Infect Dis 23: 106-110.

SEITZ, C.S., LIN, Q., DENG, H., KHAVARI, P.A., (1998). Alterations in NF-kappaB function in transgenic epithelial tissue demonstrate a growth inhibitory role for NF-kappaB. Proc Natl Acad Sci USA 95: 2307-2312.

SHILOH, Y., (2003). ATM and related protein kinases: safeguarding genome integrity Nat Rev Cancer 3: 155-168.

SIMPSON, C.L., PATEL, D.M., GREEN, K.J., (2011). Deconstructing the skin: cytoarchitectural determinants of epidermal morphogenesis. Nat Rev Mol Cell Biol.12: 565-580.

SMITH, F.J., IRVINE, A.D., TERRON-KWIATKOWSKI, A., SANDILANDS, A., CAMPBELL, L.E., ZHAO, Y., LIAO, H., EVANS, A.T., GOUDIE, D.R., LEWIS-JONES, S., ARSECULERATNE, G., MUNRO, C.S., SERGEANT, A., O'REGAN, G., BALE, S.J., COMPTON, J.G., DIGIOVANNA, J.J., PRESLAND, R.B., FLECKMAN, P., MCLEAN, W.H., (2006). Loss-of-function mutations in the gene encoding filaggrin cause ichthyosis vulgaris. Nature Genet 38: 337-342.

THIBAUT, S., CAVUSOGLU, N., DE BECKER, E., ZERBIB, F., BEDNARCZYK, A. SCHAEFFER, C., VAN DORSSELAER, A., BERNARD, B.A., (2009). Transglutaminase-3 enzyme: a putative actor in human hair shaft scaffolding? J Invest Dermatol 129: 449-459.

THORNBORROW, E.C., PATEL, S., MASTROPIETRO, A.E., SCHWARTZFARB, E.M., MANFREDI, J.J., (2002). A conserved intronic response element mediates direct p53-dependent transcriptional activation of both the human and murine bax genes. Oncogene 21: 990-999.

VEIS, D.J., SORENSON, C.M., SHUTTER, J.R., KORSMEYER, S.J., (1993). Bcl2-deficient mice demonstrate fulminant lymphoid apoptosis, polycystic kidneys, and hypopigmented hair. Cell 75: 229-240.

WAGNER, A.J., KOKONTIS, J.M., HAY, N., (1994). Myc-mediated apoptosis requires wild-type p53 in a manner independent of cell cycle arrest and the ability of p53 to induce p21waf1/cip1. Genes Dev 8: 2817-2830.

YANG, A., SCHWEITZER, R., SUN, D., KAGHAD, M., WALKER, N., BRONSON, R.T., TAPIN, C., SHARPE, A., CAPUT, D., CRUM, C., MCKEON, F., (1999). p63 is essential for regenerative proliferation in limb, craniofacial and epithelial development. Nature 398: 714-718.

YANG, Z.Z., TSCHOPP, O., DI-POI, N., BRUDER, E., BAUDRY, A., DUMMLER, B. WAHLI, W., HEMMINGS, B.A., (2005). Dosage-dependent effects of Akt1/protein kinase Balpha (PKBalpha) and Akt3/PKBgamma on thymus, skin, and cardiovascular and nervous system development in mice. Mol Cell Biol 25: 10407-10418.

ZHANG, J.Y., GREEN, C.L., TAO, S., KHAVARI, P.A., (2004). NF-kappaB RelA opposes epidermal proliferation driven by TNFR1 and JNK. Genes Dev 18: 17-22.

ZILFOU, J.T., SPECTOR, M.S., LOWE, S.W., (2005). Slugging it out: fine tuning the p53-PUMA death connection. Cell 123: 545-548. 


\section{Further Related Reading, published previously in the Int. J. Dev. Biol.}

Revisiting DNA damage repair, p53-mediated apoptosis and cisplatin sensitivity in germ cell tumors

Francesca Cavallo, Darren R. Feldman and Marco Barchi

Int. J. Dev. Biol. (2013) 57: 273-280

Causes and consequences of apoptosis in spermatozoa; contributions to infertility and impacts on development

R. John Aitken and Mark A. Baker

Int. J. Dev. Biol. (2013) 57: 265-272

Regulation of programmed cell death during neural induction in the chick embryo Anna Gibson, Neil Robinson, Andrea Streit, Guojun Sheng and Claudio D. Stern Int. J. Dev. Biol. (2011) 55: 33-43

Life-giving caspases: revealing new roles during mouse embryo preimplantation development

Dolores Busso, Calixto Dominguez, Tomas Perez-Acle and Ricardo D. Moreno Int. J. Dev. Biol. (2010) 54: 857-865

Both jnk and apoptosis pathways regulate growth and terminalia rotation during Drosophila genital disc development

Sergio Benitez, Claudia Sosa, Nicolás Tomasini and Ana Macías

Int. J. Dev. Biol. (2010) 54: 643-653

Mpl receptor defect leads to earlier appearance of hematopoietic cells/hematopoietic stem cells in the Aorta-Gonad-Mesonephros region, with increased apoptosis

Maud Fleury, Laurence Petit-Cocault, Denis Clay and Michèle Souyri

Int. J. Dev. Biol. (2010) 54: 1067-1074

Apoptosis in Drosophila: compensatory proliferation and undead cells Francisco A. Martín, Ainhoa Peréz-Garijo and Ginés Morata Int. J. Dev. Biol. (2009) 53: 1341-1347

Key apoptosis regulating proteins are down-regulated during postnatal tissue development

Shane D. Madden, Maryanne Donovan and Thomas G. Cotter

Int. J. Dev. Biol. (2007) 51: 415-424

NMDA-receptor blockade enhances cell apoptosis in the developing retina of the postnatal rat

María Hernández, Inmaculada Guerrikagoitia, Luis Martínez-Millan and Elena Vecino

Int. J. Dev. Biol. (2007) 51: 117-122

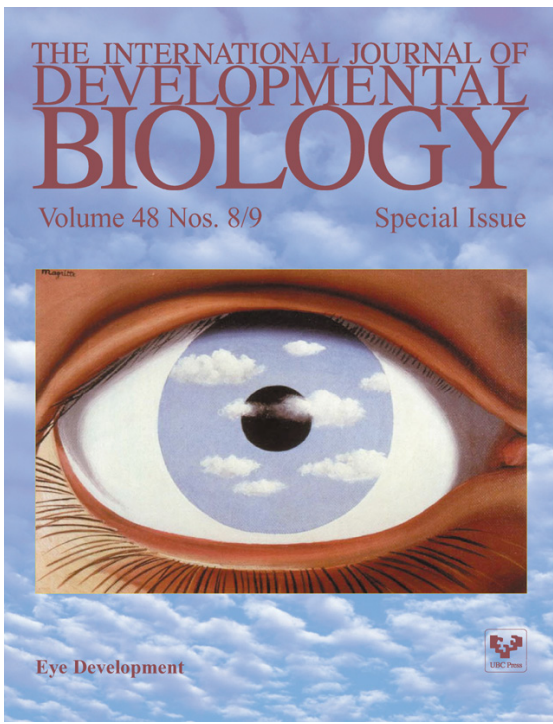

5 yr ISI Impact Factor $(2013)=2.879$

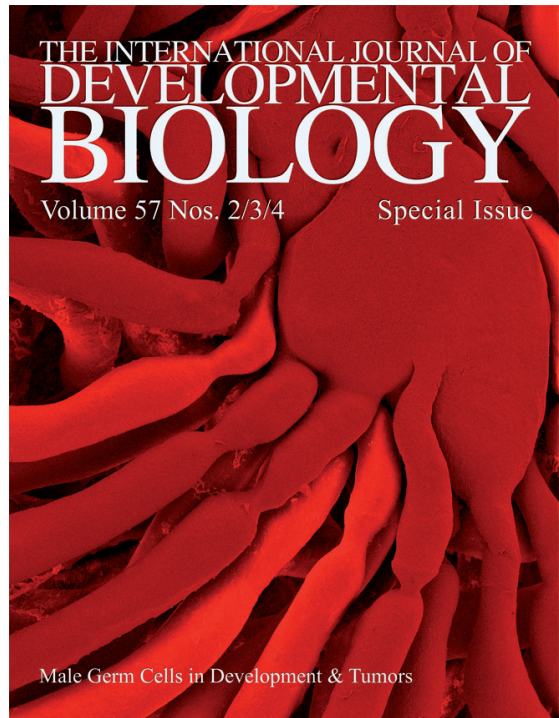

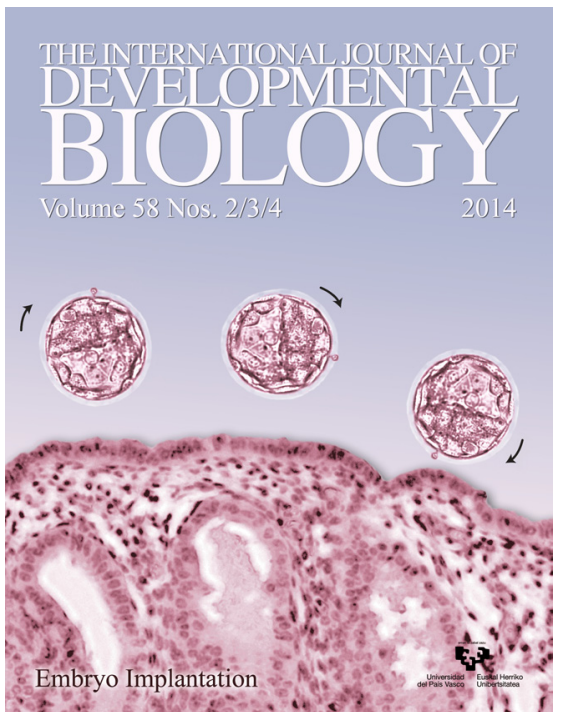
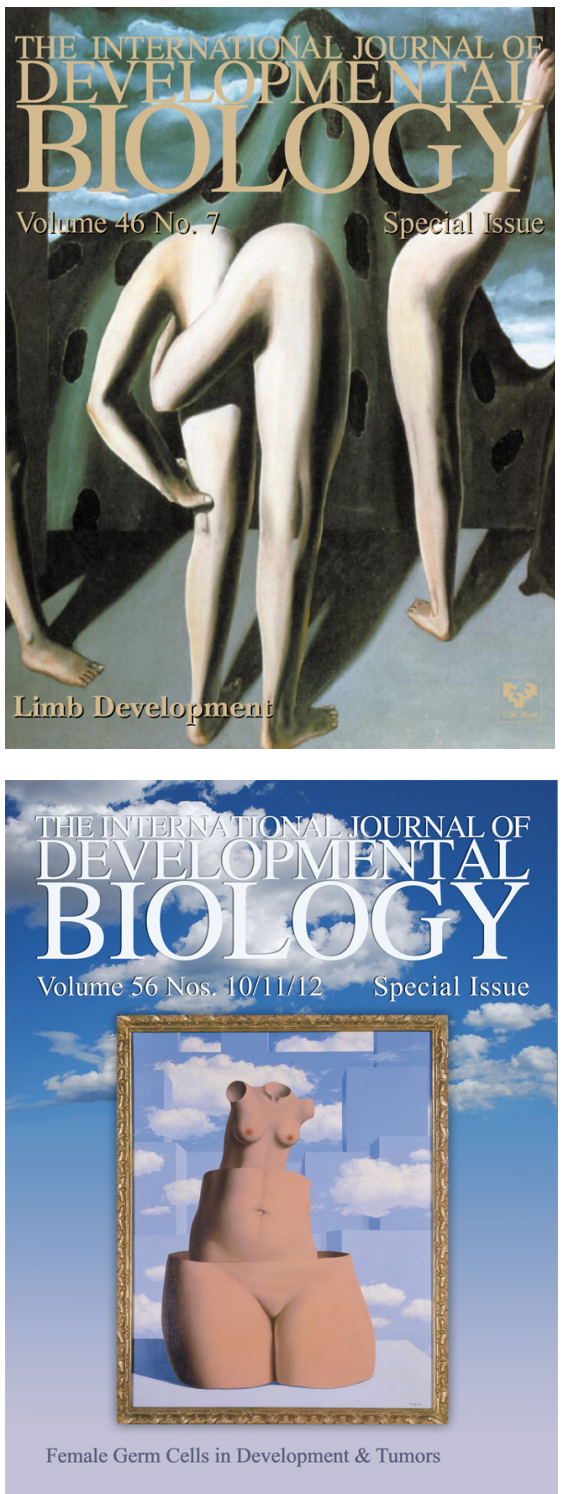